\title{
KERUDUNG SANTET GANDRUNG : SIMBOL PERLAWANAN TERHADAP KAUM SANTRI BANYUWANGI
}

\author{
oleh Yulitin Sungkowati \\ Balai Bahasa Propinsi Jawa Timur
}

\begin{abstract}
A literary work as a cultural artifact is a verbal symbol that has to be interpreted in a broad context because it correlates with the writer's intention in responding to an experienced situation. Kerudung Santet Gandrung is a novel set in Banyuwangi representing the life of practitioners of the Gandrung traditional art and that of santris, people studying at Islamic religious boarding schools. There are many symbols in the novel which potentially could be seen as indications of textual elements in the dynamic relation between the two different communities. By using a cultural hermeneutic approach, the novel strives to depict an effort in resistance made by Hasnan Singodimayan, an observer of Banyuwangi culture, to reconstruct a new and positive image of traditional artists. His resistance is an attempt to preserve Banyuwangi traditional arts which are threatened with extinction by Islamic purification movements.
\end{abstract}

Keywords: novel, Gandrung, symbol, resistance

\section{A. PENDAHULUAN}

Kerudung Santet Gandrung (selanjutnya disingkat KSG) adalah sebuah novel karya Singodimayan dan Hasnan (2003), dengan warna lokal Banyuwangi, suatu wilayah budaya di ujung timur Pulau Jawa, ranah yang belum banyak, atau bahkan, belum pernah diungkap dalam sastra Indonesia. KSG, yang diterbitkan dalam bentuk buku oleh Desantara pada tahun 2003, telah dipublikasikan sebelumnya di surat kabar harian Bali Pos dalam dua cerita bersambung dengan judul "Yang Gandrung Penari" (1986) dan "Kerudung Baju Selubung" (1987). "Yang Gandrung Penari" telah dilayarkacakan dalam bentuk sinetron oleh Televisi Pendidikan Indonesia (TPI) pada tahun 1994 dengan judul Jejak Sinden. Akan tetapi, dengan pertimbangan pengurangan biaya produksi, pengambilan gambar dilakukan di daerah Indramayu, Jawa Barat. Sinetron Jejak Sinden, yang tayang di TPI pada tahun 1995, pada masanya tergolong sukses menarik perhatian pemirsa.
Salah satu daya tarik KSG terletak pada pengungkapan kehidupan seorang penari gandrung dan pendukung seni tradisi di tengah konflik dan pergulatan konstruksinya dengan kelompok santri. Banyak penanda dalam novel ini mengindikasikan adanya elemen tekstual yang secara referensial mengacu pada realitas masyarakat Banyuwangi. Penari gandrung di Banyuwangi seringkali menghadapi dan harus memainkan peran yang dilematis karena di satu sisi dianggap sebagai kesenian asli masyarakat Using Banyuwangi sehingga banyak dimanfaatkan oleh penguasa untuk memperoleh legitimasi publik, di sisi yang lain juga dimarginalkan. Marjinalisasi kesenian gandrung tidak lepas dari pandangan kaum santri yang menganggap gandrung sebagai kesenian yang tidak bermoral dan jauh dari nilai-nilai agama Islam. Gandrung dipandang sebagai kesenian yang diliputi dengan alkohol, adegan erotis, dan seks terselubung (Anoegrajekti, 2003:xiv). Sebagai agama yang dianut oleh mayoritas masyarakat Banyuwangi, Islam dengan kelompok santrinya memainkan peran yang 
cukup penting dalam menentukan gerak kreativitas kultural kesenian gandrung (Anoegrajekti, 2003:17).

KSG mengungkap konstruksi kaum santri dalam memandang penari gandrung dan pendukung seni tradisi serta menggugat kenyataan sosial budaya yang sangat substantif. Pembaca mungkin akan tertegun dan bertanyatanya menghadapi realitas imajinatif yang disodorkan KSG. Dalam kaitannya dengan realitas objektif budaya masyarakat Banyuwangi, fenomena KSG dengan suguhan konflik dan konstruksi yang demikian, menarik untuk dikaji guna melihat makna kehadirannya di dalam masyarakat, khususnya masyarakat Banyuwangi, karena bangunan dunia imajinatif yang ada dalam KSG tidak tercipta begitu saja, tetapi diciptakan oleh seorang pengarang dengan tujuan dan kepentingan tertentu.

Kelahiran karya sastra pada dasarnya merupakan kehendak seorang pengarang untuk menanggapi situasi yang sedang atau pernah ditatapnya. Dalam menanggapi situasi yang ada dalam masyarakat, seorang pengarang tidak dapat melepaskan diri dari pengetahuan, emosi, agama, ideologi, dan kepercayaan yang dianutnya. Oleh karena itu, terciptanya sebuah karya sastra oleh seorang pengarang, secara langsung atau tidak langsung merupakan representasi sikap budaya pengarang terhadap realitas yang ditatapnya. Hal itu dapat terjadi karena dalam proses kelahiran karya sastra lebih banyak disebabkan oleh dialektika yang terus-menerus antara nilai-nilai ideal tertentu pengarang dengan nilai-nilai realitas sosial.

Dengan demikian, karya sastra sebagai simbol verbal memiliki beberapa peranan, diantaranya sebagai cara pemahaman (mode of comprehension), cara perhubungan (mode of communication), dan cara penciptaan (mode of creation). Di samping itu, sastra juga dapat melakukan perlawanan terhadap sistem sosial (Kuntowijoyo, 1987: 127). Sastra dapat merupakan konfirmasi terhadap kenyataankenyataan sosial apabila ia semata-mata melukiskan tanpa menyatakan sikap pada sistem sosial. Sastra jenis ini lazim disebut sastra simtomatik karena hanya menyajikan gejala-gejala sosial. Sastra yang menganalisis masyarakatnya dan menyatakan pendapatnya secara sadar disebut sebagai sastra diagnostik. Sastra jenis ini mencoba merekayasa masyarakatnya. Sastra juga dapat menjadi kritik sosial yang mencoba melakukan perlawanan terhadap masyarakatnya yang sering disebut sastra dialektik. Dalam dunia sastra juga dikenal adanya sastra alternatif, yaitu sastra yang mencoba membebaskan sastra sebagai sistem simbol dari masyarakatnya (Kuntowijoyo, 1987: 146-147). Dalam konteks tersebut, KSG patut diduga sebagai karya yang menjadi kritik sosial dan mencoba melakukan perlawanan terhadap masyarakatnya.

Untuk mengungkap makna kehadiran novel KSG sebagai benda budaya di tengah masyarakat Banyuwangi, penulis menggunakan perspektif tafsir budaya Clifford Geerzt yang memandang bahwa benda budaya baru bermakna apabila diberi makna oleh manusia. Tanpa peran pembaca sebagai penafsir, karya sastra hanyalah artefak (Mukarovsky dlm. Teeuw, 1988:191). Clifford Geerzt memberikan tekanan pada manusia sebagai pemberi makna dalam interpretasi. Geerzt melihat kebudayaan sebagai konsep semiotis dan percaya pada Mark Weber bahwa manusia adalah seekor binatang yang bergantung pada jaringan-jaringan makna yang ditenunnya sendiri. Dengan demikian, analisis kebudayaan bukan untuk mencari hukum, melainkan sebuah ilmu yang interpretatif untuk mencari makna (2000:5). Kebudayaan tidak berada dalam kepala seseorang. Meskipun tidak bersifat fisik, kebudayaan bukanlah entitas tersembunyi (2000:12), tetapi bersifat publik karena makna juga bersifat publik (2000:15).

Dalam melihat kebudayaan sebagai konsep semiotis, Geerzt mengikuti pandangan Charles Sanders Peirce yang menempatkan tanda dan acuannya di luar pengguna tanda itu, yaitu ke unsur-unsur dan realitas ekstern. Tanda mempunyai tiga komponen, yaitu representamen yang merupakan unsur realitas luar individu yang 'mewakili' suatu unsur lain yang disebut objek. Dengan kata lain, 
representamen berfungsi sebagai penanda dan objek sebagai tinanda. Akan tetapi, relasi fungsional itu baru terjadi jika saling dikaitkan oleh interpretan atau penafsir (Masinambow, 2004:18). Oleh karena itu, kehadiran penafsir dalam proses interpretasi sangat penting karena simbol atau lambang tidak dapat merepresentasikan sesuatu tanpa kehadiran manusia. Manusialah yang membuat sesuatu, yang disebut simbol, merepresentasikan sesuatu karena makna simbol tidak terletak pada simbol itu, tetapi diberikan oleh manusia sebagai pengguna simbol (Ahimsa-Putra, 2002:2).

\section{B. MASYARAKAT DAN BUDAYA BANYUWANGI}

Kebudayaan Banyuwangi telah mengalami proses yang cukup panjang, sepanjang perjalanan sejarah kerajaan Blambangan sampai menjadi Banyuwangi. Kerajaan Blambangan merupakan kerajaan Jawa Hindu terakhir di ujung timur Pulau Jawa. Sebelum menjadi bagian kerajaan Majapahit, Blambangan tidak pernah lepas dari incaran kerajaan lain yang tertarik dengan kondisi geografisnya yang strategis. Serangkaian hubungan dan penaklukan oleh kerajaankerajaan lain menyebabkan masyarakat Banyuwangi memiliki pola budaya tersendiri sebagai masyarakat multietnis yang mampu mengakomodasi keragaman budaya. Meskipun demikian, yang lebih dikenal untuk mewakili ciri khas Banyuwangi yang sekarang adalah masyarakat Using yang dianggap sebagai penduduk asli Banyuwangi. Penyerapan dan persilangan budaya asli Blambangan dengan budaya lain tidak hanya melalui peperangan, tetapi juga melalui saudagar-saudagar dari Gujarat dan Persia yang membawa budaya Islam pada sekitar abad XVI. Para Wali, terutama yang langsung berhubungan dengan masyarakat Blambangan adalah Syeh Wali Lanang atau Syeh Maulana Iskhak yang menikah dengan putri Blambangan dan melahirkan putra Raden Paku atau Sunan Giri (Darusuprapta, 1984: 14-15).

Selain menyebarkan agama Islam, para wali juga mendekati masyarakt lewat seni budaya, mengadopsi unsur-unsur dari Arab dan Persia. Kerajaan-kerajaan Islam, para wali, dan para pendatang dari Bugis, Mataram, Melayu, dan Jawa Tengah berpengaruh besar terhadap penyebaran agama Islam di Blambangan terbukti kini mayoritas penduduk Banyuwangi beragama Islam. Adanya kaum pendatang juga menyebabkan penduduk Banyuwangi memiliki budaya yang beragam sesuai dengan latar belakang daerah asalnya. Mereka memiliki berbagai acara tradisi dan adat, antara lain bentuk-bentuk selamatan untuk siklus atau daur kehidupan manusia hingga meninggalnya, seperti tingkeban, kelahiran (sepasaran, selapanan), perkawinan, dan kematian. Dalam upaca-upacara itu tidak jarang digunakan kegiatan seni tradisi pertunjukan untuk hiburan. Selain tradisi selamatan dan kendhuri, upacara bersih desa dan upacara petik laut, sebagian masyarakat Banyuwangi tampaknya masih tetap mengikuti ajaran yang ditinggalkan oleh nenek moyang (leluhur) yang beragama Hindu terlihat dalam upacara tradisi mereka yang tetap mengikutsertakan pembakaran dupa (kemenyan) meskipun sebagian besar penduduk Banyuwangi telah menganut ajaran agama Islam (Soeprihati, 2001:45-46). Kuatnya akar Hindu dalam masyarakat Banyuwangi sekarang karena pada masa lalu Blambangan adalah kerajaan yang lebih tua daripada Majapahit dan merupakan kerajaan yang paling gigih bertahan terhadap usaha pengislaman dan serangan dari Mataram (Partaningrat dalam Soeprihati, 2001:3).

Perjalanan sejarah yang panjang itu telah membentuk karakteristik budaya masyarakat Banyuwangi. Ciri khas karakteristik budaya Using yang menonjol adalah sinkretis, yakni dapat menerima dan menyerap budaya masyarakat lain untuk diproduksi kembali menjadi budaya Using. Budaya Using juga akomodatif terhadap kekuatan supranatural, gaib, dan magis. Sinkretisme agama Islam dengan kepercayaan animisme dinamisme yang terakumulasi dalam keyakinan terhadap dhanyang, tampak dalam upacara-upacara ritual seperti Seblang, Barong, Kebo-Keboan, sedangkan sinkretisme dalam 
dimensi kesenian adalah Praburara dan Hadrah Kuntulan (Singodimayan dalam Saputra, 2003:53). Oleh karena itu, budaya santet dan sihir yang marak di kalangan masyarakat Using tidak lagi dipandang sebagai sesuatu yang 'menghebohkan', tetapi justru merupakan bagian integral dari khasanah budaya tradisional mereka. Mantra Using meliputi mantra bermagi putih, kuning, merah, dan hitam. Mantra bermagi putih digunakan untuk penyembuhan, mantra bermagi kuning dan merah untuk pengasihan, dan mantra bermagi hitam untuk pembunuhan. Mantra bermagi hitam disebut sihir, sedangkan mantra bermagi kuning dan merah disebut santet (Saputra, 2003). Persoalan santet tidak lepas dari rangkaian tradisi atau mekanisme budaya yang penuh dengan warna kasih-sayang, yakni tradisi pencarian jodoh. Masyarakat Using memiliki tradisi pencarian jodoh melalui gredhoan, bathokan, dan mlayokaken atau colongan. Akan tetapi, apabila ketiga cara itu gagal dilakukan, orang Banyuwangi akan menggunakan jalan pintas dengan santet (Saputra, 2003; 85).

Kelompok yang paling dekat dengan berbagai tradisi, termasuk tradisi bermantra adalah kelompok abangan yang pada umumnya berprofesi sebagai petani, bermukim di desadesa, dan merupakan mayoritas di dalam masyarakat Banyuwangi (Koesnadi dalam Pujisaputra, 2003:239). Secara formal, mayoritas masyarakat Using beragama Islam, $95 \%$, tetapi sifat sinkretis yang melekat pada budaya Using tidak mudah hilang hingga Islam yang mereka anut sangat akomodatif terhadap berbagai fenomena tradisi lokal dan pada umumnya berafiliasi pada nahdatul Ulama. Selain menjalankan syariat Islam, mereka juga menjalankan upacara-upacara ritual, baik yang bersifat individual maupun sosial yang populer dengan nama slametan, percaya pada mahluk halus, dan menyakini adanya kekuatan magi. Mereka memiliki pandangan dunia slamet (dengan uapacara slametan) untuk menjaga keselarasan antara makrokosmos dan mikrokosmos sehingga menjadi 'pelaku utama'dan pendukung tradisi. Selain kelompok abangan, dalam masyarakat Banyuwangi juga ada kelompok santri. Ciri kelompok ini adalah melaksanakan secara cermat dan teratur peribadatan Islam, seperti salat, puasa, dan haji dengan di topang tradisi pesantren. Banyak orang Using lebih mementingkan pendidikan pesantren tradisional yang menitikberatkan pada pengajaran pembacaan Al-Quran dan ilmu agama daripada pendidikan formal atau umum, artinya bukan sekolah dengan fasilitas memadai. (Saputra, 2003:245). Kelangsungan seni tradisi terusik ketika proyek purifikasi ajaran Islam mulai merambah wilayah Banyuwangi.

Muhammadiyah adalah organiasi keagamaan yang menempatkan purifikasi ajaran Islam sebagai salah satu tujuannya (Fajar, 1999:100). Dalam pandangan Muhammadiyah, Islam mengajari umatnya untuk memiliki aqidah yang murni, bersih dari berbagai macam syirik maupun khurafat (tahayul atau gugon tuhon) dan bid'ah. Muhammadiyah merasa memiliki kewajiban untuk mengembalikan kemurnian Islam karena dalam praktiknya masih banyak orang Islam yang percaya terhadap berbagai benda keramat (Pasha dan Darban, 2002:114115).

Wilayah Banyuwangi tidak luput dari pengaruh gerakan pemurnian Islam tersebut. Meskipun jumlah pengikut Muhammadiyah minoritas di Banyuwangi, pada umumnya mereka berada di pemerintahan atau dekat dengan penguasa sehingga pengaruhnya kuat dalam membentuk konstruksi sosial atau pengambilan keputusan. Kehadiran Muhammadiyah menjadi ancaman bagi kelangsungan hidup berbagai tradisi masyarakat Banyuwangi yang memiliki karakteristik sinkretik. Hasnan Singodimayan (dalam Saputra, 2003:247) merasa prihatin melihat gerakan Muhammadiyah yang memandang negatif keberadaan ngelmu, berbagai upacara ritual atau slametan, dan seniseni tradisi yang melibatkan dukun yang merupakan karakteristik budaya Banyuwangi. Hasnan melihat bahwa Muhammadiyah memandang perilaku dukun sebagai warisan masyarakat 'tribal' yang terbelakang, yang tidak 
sesuai lagi dengan perkembangan zaman, aqidah Muhamadiyah, Alquran, dan Hadis. Dengan demikian, santri Muhamadiyah menilai musyrik hukumnya bagi mereka yang meminta bantuan kepada dukun, baik dalam hal penyembuhan penyakit, ramalan nasib atau keberuntungan, maupun dalam hal pengasihan atau santet (Saputra, 2003: 245-246).

\section{KEHIDUPAN GANDRUNG DI BANYUWANGI}

Armaya (2002: 10) melihat Gandrung sebagai kesenian asli Banyuwangi yang memiliki sejarah cukup panjang dan tidak lepas dari dinamika peperangan kerajaan Blambangan. Gandrung merupakan persembahan rasa syukur masyarakat Banyuwangi kepada Dewi Sri. Sebagaimana masyarakat agraris lainnya, masyarakat Banyuwangi juga memuja Dewi Sri dengan berbagai ritual tarian sebagai perwujudan rasa syukur. Ritual gandrung dilakukan untuk mewadahi kekuatankekuatan kosmis dan sumber magis yang memberikan kesejahteraan bagi masyarakat sehingga penari gandrung dipandang sebagai titisan Dewi Sri dan memiliki kedudukan yang sangat istimewa (Singodimayan $\mathrm{dlm}$. Anoegrajekti, 2003:24).

Gandrung yang semula dimainkan oleh laki-laki dalam perkembangannya kemudian ditarikan oleh perempuan. Sejak ditarikan oleh para perempuan inilah gandrung menuai banyak sorotan. Hal itu tidak lepas dari busana yang dikenakan, waktu pementasan, dan babakan dalam pementasan Gandrung (Armaya, 2002:15-16). Pergeseran pandangan masyarakat terhadap Gandrung disebabkan oleh beberapa hal. Endro Wilis (2002) melihat bahwa konstruksi negatif Gandrung tidak lepas dari peran para pendatang (Jawa), yang masih dianggapnya sebagai wong kulonan, yang membawa malapetaka seperti Mataram ketika menyerang Blambangan. Endro Wilis (2002) berpendapat sebagai berikut.

Hal ini erat sekali hubungannya dengan nasib penari Gandrung. Dulu pada zaman Belanda orang hormat dan segan terhadap Gandrung. Seorang gadis apabila ditunjuk menjadi penari Gandrung, maka dia beserta keluarganya akan bangga. Tetapi para pegawai negeri di daerah yang terdiri dari orang pendatang (Jawa), Gandrung dijadikan "teledheg". Untuk memuaskan kepentingan arisan, disertai minum bermabuk-mabukan yang menimbulkan keributan tidak lagi menjadi (tontonan) atau hiburan yang dihormati dan disayangi. Nah, sejak itulah nilai Gandrung turun makin drastis. Sekarang banyak orang malu menjadi Gandrung. Ini satu kenyataan pahit....

Kaum santri atau agamawan kemudian menjadi faktor penentu kelangsungan hidup seni Gandrung ketika purifikasi Islam nusantara yang bebas dari khurafat dan bid'ah merambah Banyuwangi dan pelan-pelan mengikis kreativitas kultural, seperti mitos, mantra-mantra, dan sesaji. Mereka menolak Gandrung yang dianggap sebagai seninya orang-orang kafir dan musyrik karena mengumbar aurat dan nafsu seksual.Tidak kurang dari Ketua Majelis Ulama Islam (MUI) Banyuwangi turun tangan "menertibkan" dengan memberikan saran supaya Gandrung dapat tampil Islami, baik dalam hal pakaian maupun cara berjogednya. Masyarakat santri (kelas menengah kota) menganggap Gandrung sebagai kesenian yang amoral karena diwarnai oleh minuman keras, mabuk-mabukan, perjudian, prostitusi, dan seks terselubung (Anoegrajekti, 2003). Kehidupan penari Gandrung di luar pentas seringkali diliputi oleh berbagai tuduhan dan prasangka buruk, khususnya dari kaum santri. Mereka memandang para perempuan seni tradisi Gandrung itu memiliki profesi ganda, yaitu sebagai penari merangkap wanita tuna susila yang permisif terhadap free sex. Tidak dapat dipungkiri bahwa memang ada penari Gandrung yang menunjukkan perilaku buruk dalam hal sex, namun tidak sedikit pula yang menjalani profesinya secara profesional dan 
bersih (Suyono, 1998:53). Kaum santri memandang para penari Gandrung sebagai perempuan murahan yang dapat dibeli oleh laki-laki (Suyono, 1998:54). Pandangan kaum santri tersebut pelan-pelan mengikis kebanggaan para pendukung seni Gandrung sehingga banyak gadis dan keluarga Banyuwangi yang pada mulanya bangga sebagai penari Gandrung menjadi malu. Konstruksi yang dibangun oleh kaum santri dan dampaknya terhadap pendukung seni tradisi itu merupakan ancaman nyata terhadap eksistensi seni gandrung Banyuwangi (Anoegrajekti, 2003).

\section{KSG MEMBANGUN KONSTRUKS BARU}

\section{D.1 Penari Gandrung dan Penerus Seni Tradisi sebagai Manusia Mulia}

Konstruksi baru itu telah tercermin dalam judul Kerudung Santet Gandrung. Sebagaimana telah dikemukakan pada subbab A bahwa dalam masyarakat Banyuwangi, budaya santet biasanya dipelihara dan digunakan oleh kelompok abangan, termasuk para penggiat seni Gandrung. Akan tetapi, KSG menempatkan santri (melalui simbolisasi kerudung) sebagai pihak yang menyantet abangan (melalui simbolisasi gandrung). Judul sebagai identitas karya dan jendela untuk melihat ke dalam bangunan dunia KSG telah mengarahkan pembaca untuk melihat konstruks baru atas realitas gandrung di tengah pergulatan konstruksi dan konfliknya dengan kaum santri di Banyuwangi. Pengacuan pada referensi masyarakat dan budaya Banyuwangi menjadi sebuah kebutuhan untuk menangkap lebih jauh "suara" yang terkandung dalam KSG sebagai benda budaya dalam upaya untuk memaknai kehadirannya.

Sebuah bangunan dunia kaum seni tradisi gandrung dan kaum santri yang berlawanan dengan konstruksi kaum santri dalam realitas objektif masyarakat Banyuwangi segera terbentuk ketika pembacaan telah menjelajah hingga halaman terakhir KSG. KSG secara terbuka menyodorkan fenomena baru yang resisten terhadap fenomena yang berkembang dalam masyarakat Banyuwangi yang menunjukkan adanya korelasi antara KSG sebagai benda produk budaya dengan masyarakat Banyuwangi yang melahirkannya. Konstruks baru penari gandrung itu tampaknya dibangun berlandaskan kesadaran keagamaan, sejarah, dan keinginan untuk mempertahankan seni tradisi sebagai warisan budaya dan penanda identitas masyarakat Banyuwangi. Kehadiran KSG tampaknya tidak dapat dipisahkan dengan kenyataan hidup seni tradisi Banyuwangi yang kian terancam punah oleh makin kuatnya peran santri dengan gerakan purifikasinya sebagaimana telah dikemukakan pada subbab C.

Di saat dia melihat wajah Merlin memancarkan sinar cemerlang yang tak terlihat pada orang lain di kanan kirinya. Terutama di saat penari Seblang kesurupan. Sinar itu terkesan seperti cahaya yang pernah dilihat masyarakat di Gresik di pemakaman Sunan Giri pada bulan puasa yang lalu.

....

.... Cerita tentang Sunan Giri atau Sunan Paku, telah menambah perbendaharaan otaknya, bahwa ibu suri Raden Paku yang dijuluki Sunan Giri berasal dari Blambangan yang bernama Sayu Sekardalu, putri tunggal Wong Agung Sembuyu yang dikenal dengan nama Pangeran Dedali Putih. Apakah tidak mungkin, Merlin keturunannya Sayu Sekardalu yang sekian puluhnya atau bagian dari titisan jiwanya (hlm. 126-127)

Berbeda dengan pandangan budayawan Banyuwangi sebelumnya yang menganggap penari gandrung sebagai penjelmaan atau titisan sang dewi kesuburan, Dewi Sri, KSG menyodorkan citra penari gandrung sebagai kemungkinan titisan Puteri Sayu Sekardalu. Pilihan identifikasi pada sosok Puteri Blambangan itu, bukan Dewi Sri, tampaknya bukan suatu kebetulan atau sekadar menautkannya dengan perempuan dari kelas 
tertinggi dalam struktur kekuasaan kerajaan Blambangan pada masa dulu, tetapi juga pada alasan keagamaan. Sayu Sekardalu adalah puteri raja Blambangan yang menikah dengan Syekh Maulana Ishak, penyebar Islam pertama di bumi Banyuwangi. Ia menjadi orang pertama dari unsur kekuasaan Blambangan yang masuk Islam dan kemudian melahirkan seorang putera bernama Raden Paku. Raden Paku kemudian lebih dikenal sebagai Sunan Giri, satu dari sembilan Wali Songo yang gigih menyebarkan Islam di tanah Jawa. Dengan mencitrakan Merlin sebagai perempuan yang memancarkan sinar dan menyejajarkan sinar itu dengan cahaya yang memancar dari makam Sunan Giri, KSG tidak hanya menunjukkan adanya keterkaitan ibu dan anak antara Sayu Sekardalu dan Sunan Giri, tetapi menempatkan sang penari gandrung sebagai perempuan suci dan agung sejajar dengan kesucian dan keagungan ibu dan anak tersebut sehingga sepantasnya dihormati dan dimuliakan, bukan dimarginalkan dengan tuduhan amoral. Pengaitan dengan Puteri Sayu Sekardalu dan Sunan Giri menunjukkan bahwa KSG ditujukan terutama kepada kaum santri yang selama ini memarginalkan para perempuan seni tradisi.

Santri dalam KSG mengarah secara khusus pada santri Muhammadiyah. Berbeda dengan santri NU yang akomodatif terhadap tradisi lokal, santri Muhammadiyah dengan gerakan purifikasinya ingin membersihkan Islam dari kurafat dan bid'ah, termasuk perdukunan. Jauh sebelum gerakan purifikasi merambah Banyuwangi, masyarakat Banyuwangi sudah mengenal Islam yang kemudian disinkretiskan dengan kepercayaan animisme, dinamisme, dan agama Hindu yang sudah lebih dulu dipercaya masyarakat. Singodimayan sebagai seorang budayawan Banyuwangi melihat ancaman nyata tersebut sehingga menghadirkan penari Gandrung yang bersih dan mulia, yang menari dan berlagu karena panggilan jiwa sebagai orang Using dan pewaris sah seni tradisi nenek moyangnya. Konstruksi itu nyata berlawanan dengan pandangan kaum santri Muhammadiyah pada umumnya yang memandang penari Gandrung sebagai sosok murahan dan jauh dari nilai-nilai agama.

Para pendukung seni Gandrung memang akrab dengan dunia perdukunan, tetapi tidak seperti yang dituduhkan oleh kalangan santri. Kelompok seni tradisi dalam KSG menggunakan jasa dukun hanya untuk mempercantik gandrung dan menyingkirkan hujan agar pentas gandrung berjalan dengan baik. Dukun Sawang ditampilkan sebagai dukun yang baik untuk menunjukkan bahwa tidak semua dukun menggunakan ilmunya untuk mencelakai orang. Berlawanan dengan kalangan pendukung seni tradisi yang dicitrakan baik, santri Muhammadiyah yang eksklusif justru dikonstruksi sebagai manusia jahat. Nazirah, yang selalu menuduh para pendukung seni tradisi sebagai pengguna santet, justru menggunakannya sendiri untuk menyakiti Merlin.

Di hadapan dukun itu, Nazirah mengurai cerita kebohongannya tentang maksud kedatangannya. Dikatakannya sebagai istri yang diduakan suaminya, maka Nazirah mengharap pertolongan dukun untuk mencabut "sensreng" kecantikan yang dipakai oleh madu suaminya yang bernama Merlin.

Nazirah dengan suara yang mencekam menjelaskan semua yang diminta itu secara ngawur menurut bayangannya sendiri. Rambutnya ikal mayang, lehernya jenjang pinang muda, dadanya montok seronok, pinggulnya ugal ugis, pahanya dan betisnya semulus batang pisang, jari-jarinya, jari-jarinya....jari

Tangan dan jari-jari dukun telah meraba rambutnya dari belakang sambil berucap, "Sensreng, sensreng, rontoklah rambut perempuan."...

(hlm.137-138) 
Kejahatan dan kemunafikan santri Nazirah secara jelas tampak karena langsung dipertentangkan dengan penari gandrung yang dikonstruksi mulia. Dalam kerangka suguhan oposisional itu, yang baik tampak kian baik dan yang buruk menjadi kian jelas keburukkannya. Narasi KSG secara jelas berpihak kepada perempuan seni tradisi dan para pendukungnya. Bahkan, pengakuan atas keagungan dan kemuliaan penari gandrung itu tidak hanya dinarasikan melalui penyejajarannya secara fisikal dengan puteri Sayu Sekardalu dan Sunan Giri, tetapi juga dari moralitasnya. Kesalehan dan kesadaran untuk memaafkan orang lain sebagai salah satu ajaran Islam seharusnya lebih dimiliki oleh Nazirah yang santri dan pendakwah, tetapi ia justri dihadirkan sebagai pendengki dan pendendam. Akhlak mulia itu justru dimiliki oleh sang penari gandrung yang senantiasa dihinanya sebagai manusia tidak bermoral. Melalui Nazirah dan Merlin, KSG menyodorkan satu pemikiran bahwa moralitas tidak bisa dan tidak dapat diukur dari pakaian. Kaum santri terjebak dalam cara pandang yang formalistik, bukan esensialistik. Pakaian para penari gandrung yang ketat dan terbuka diidentikkan degan longgarnya moralitas mereka, sementara para santri yang berbusana kerudung tertutup dianggap suci. Narasi KSG menohok pandangan formalistik tersebut secara keras, seperti berikut.

Betapa agungnya jiwa perempuan desa itu. Kejahatan seseorang dibalas dengan kebaikan dan betapa busuknya perbuatan mantan istrinya itu, sekalipun bentuk luarnya tertutup dengan busana kerudung, tapi di dalamnya sebusuk binatang. (hlm. 194)

Moralitas yang baik justru dimiliki oleh para pendukung seni tradisi. Dalam teks KSG, santri Nazirah "dipaksa" berlutut mengakui keunggulan moral dan keagungan hati seorang penari Gandrung.

"Maaf, kami baru mendengar pagi tadi dari Azizah. Salam dari Mas Iqbal untuk Mbakyu. "Semoga lekas sembuh", ucapan disampaikan dengan sangat tulus, seraya menyerahkan sebuah amplop yang berisi uang dua ratus ribu rupiah.

"Sementara kami cuma bisa membantu sekian".

Terkaca pada mata Nazirah genangan air yang bergulir secara perlahan, butirbutir bening yang meleleh di pipinya. Nazirah tak tahan melihat putihnya hati yang dibawa Merlin. Tanpa terkendali oleh rasa yang menghujam dadanya, Nazirah langsung memeluk Merlin yang sudah duduk di sampingnya.

"Maafkan aku Merlin, maafkan."

…

Mereka yang hadir di ruangan itu merasa terheran-heran melihat adegan yang aneh itu. Tokoh yang tegar bicara di atas mimbar, telah terisak-isak dalam pelukan tilas seorang penari. Lantas di mana kesaktiannya dalam sumpah "baiat" yang pernah diucapkan? (hlm. 156157)

Dukungan dua tokoh santri, yaitu Iqbal dan Azizah, dalam KSG menunjukan adanya perlawanan terhadap komunitasnya. Perlawanan itu datang dari komunitas santri sendiri yang lebih tahu kemunafikan mereka dibandingkan dengan orang di luar. Iqbal dan Azizah melihat gerakan purifikasi bukan untuk menggusur atau meniadakan eksistensi kelompok lain. Iqbal dan Azizah melihat komunitasnya yang santri adalah orang-orang picik yang melihat segala sesuatu dari sudut pandangnya sendiri. Azizah mempertanyakan pakaian para muslimah yang dikenakan di keluarganya dan menantang keluarganya untuk menunjukkan kelebihannya dibandingkan dengan komunitas yang selalu direndahkannya. Cara pandang kaum santri yang formalistik mendapat gugatan tajam dalam KSG melalui narasi Azizah.

“Apakah saya harus bekerja di tambak dengan memakai kerudung? Apakah 
saya mengendarai mobil seperti sekarang ini memakai kain panjang?" (hlm. 100)

\footnotetext{
"Kurang apa tentang agama Paman? Di sebelah rumahnya telah dibuat mushala. Di lahan pertambakan telah disediakan masjid kecil untuk para pekerja. Insya Allah tahun depan paman akan menunaikan rukun hajinya bersama bibi." (h. 101).

Lagu yang dinyanyikan Merlin itu karangan Iqbal, isinya mengajak orang berbuat baik. Apa bedanya dengan lagu kasidah?"

Mereka semua terdiam. Tapi seorang diantaranya lalu menjawab dengan nada bertanya.

"Bagaimana dengan busana yang dipakainya?"

Maka seperti yang pernah dijelaskan Azizah ketika Rafiqah bermalam di rumahnya. Bahwa setiap negara dan daerah memiliki busana tradisional dengan ciri keindahan masing-masing.

"Yang dikenakan di Blambangan atau Indonesia adalah ciri pakaian Blambangan dan Indonesia." (h. 105).
}

Oleh karena itu, Iqbal dan Azizah keluar dari tradisi keluarganya dan justru masuk dalam komunitas yang menjadi sasaran gerakan purifikasi. Upaya yang dilakukan Iqbal menunjukkan ciri khas tradisi budaya Banyuwangi yang sinkretis. Keislamannya tidak untuk menggusur eksistensi kelompok lain, tetapi membawa Islam masuk ke dalam budaya yang ada agar dapat mewarnainya dari dalam. Dengan demikian, kedua budaya itu dapat tetap hidup dan saling memperkaya. Hal itu ditunjukkan dengan menciptakan gendinggending Gandrung yang esensinya mengajak orang berbuat kebaikan sehingga tidak ubahnya dengan lagu-lagu qasidah. Iqbal juga melawan arus keluarganya dengan menikahi penari
Gandrung. Tindakan Iqbal ini ternyata justru menjadi dakwah yang efektif karena ia dapat menarik Merlin untuk belajar membaca $\mathrm{Al}$ Quran. Meskipun seorang Muhammadiyah, Iqbal juga tidak segan-segan menyelenggarakan tahlilan demi menghormati orang lain yang mempercayainya. Ia tidak keberatan meminta bantuan seorang dukun putih untuk membantu menyembuhkan Nazirah yang terkena santetnya sendiri ketika dokter sudah tidak sanggup.

Tahlilan itu diselenggarakan cukup mewah dan meriah melebihi ketika akad nikahnya tiga bulan yang lalu di Desa Candipura. Acara yang bertentangan dengan keyakinan pribadinya itu, dilaksanakan sekedar untuk menyenangkan hati Salehak, mertuanya yang baru itu. (hlm. 76)

Otaknya terasa terbelit oleh berbagai pertanyaan dan larangan untuk percaya pada dukun. Tapi kenyataan yang tampak di matanya merupakan suatu yang harus dihadapinya. Dokter Mas'unah merasakan apa yang bergelut dalam dada Iqbal sorotan matanya menukik tajam pada bumi kenyataan. Kenyataan yang bermain secara gamblang di hadapannya, kematian Tasrif oleh sumpahnya dan buncit perut Nazirah oleh dukun.

Dalam yang sejenak itu, Iqbal teringat pada mertuanya, pada Merlin istrinya. Pada lingkungan yang masih percaya pada dukun, pada keadaan di luar perhitungan akal pikirannya. (hlm. 188)

Tahlilan dalam peringatan kematian seseorang dan meminta pertolongan pada dukun merupakan bagian yang dianggap bid'ah oleh Muhammadiyah dan menjadi sasaran dakwah untuk dihilangkan karena tidak sesuai dengan ajaran Islam. Akan tetapi, dalam novel ini Iqbal yang Muhammadiyah melakukannya 
meskipun hanya untuk menghormati dan membantu orang lain.

\section{D.2 Pendidikan Pesantren Tradisional Tidak Dapat Memberikan Jaminan Masa Depan}

Sebagaimana telah diungkapkan pada bagian kehidupan sosial budaya masyarakat Banyuwangi, mayoritas masyarakat Banyuwangi lebih menyukai pendidikan pesantren. Pendididkan pesantren yang menjadi tujuan masyarakat Banyuwangi adalah dalam pengertian pengajaran Islam secara tradisional, yaitu membaca Al-Quran, bukan pondok pesantren modern yang di dalam kurikulum pengajarannya telah memasukkan mata pelajaran ilmu pengetahuan. Pondok pesantren merupakan sistem pendidikan khas Indonesia yang sudah berkembang sejak zaman penjajahan Belanda. Pada masa penjajahan, pondok pesantren mempunyai peran yang besar dalam menanamkan semangat nasionalisme. Akan tetapi, muatan isi dalam sistem pengajaran pondok pesantren sudah tidak sesuai lagi dengan tuntutan zaman. Banyak pondok pesantren yang hanya mengajarkan 'mata pelajaran agama' dalam arti sempit, yaitu terbatas pada fiqh, pelajaran bahasa Arab, terjemahan dan tafsir, hadis, tasauf, dan lainlain. Mata pelajaran yang bersangkutan dengan kehidupan keduniaan yang sering disebut dengan ilmu pengetahuan belum diperkenalkan. Padahal, melalui ilmu-ilmu pengetahuan seseorang akan mampu melaksanakan tugastugas keduniaan sebagai Khalifah Allah di bumi (Pasha dan Darban, 2002:116).

KSG memperlihatkan nasib tragis yang dialami para santri dengan latar pendidikan pesantren tradisional. Mereka yang menuntut ilmu di luar pondok pesantren, khususnya pada sekolah kejuruan menjadi orang yang sukses dalam bidang ekonomi dan inklusif dalam pandangannya. Hal itu dapat dimaknai sebagai bentuk perlawanan terhadap masyarakat santri Banyuwangi yang lebih percaya pada pendidikan pesantren dan meninggalkan pendidikan formal umum. Mereka yang berlatar pendidikan pesantren tradisional hanya dibekali pendidikan agama, tetapi tidak mendapatkan ilmu pengetahuan praktis sehingga ketika mereka kembali berhadapan dengan dunia, mereka tidak memiliki bekal keterampilan dan pengetahuan yang cukup, selain menjadi guru agama. Nazirah menolak mentah-mentah ketika adiknya, Nasran, hendak di sekolahkan pada Sekolah Perikanan. Ia lebih percaya pada pendidikan pondok pesantren. Setelah keluar dari pesantren, Nasran tidak hanya sulit mendapatkan pekerjaan, selain menjadi guru mengaji, tetapi juga melakukan tindakan yang jauh dari nilai-nilai Islam. Masnub dan Tasrif hanya dapat menjadi guru agama kontrak pada Sekolah Dasar sehingga ketika menghadapi kesulitan keuangan ia terpaksa mencuri perhiasan kakaknya.

Adik satu-satunya yang pernah diminta Iqbal untuk meneruskan pendidikannya ke sekolah perikanan menengah atas pernah ditolaknya mentahmentah, yang kemudian digantikan oleh Azizah, kemenakan Iqbal sendiri yang sekarang menjadi orang kepercayaannya. Bergaji melebihi gaji bapaknya yang pegawai kantor kecamatan itu, adapun Nasran, adiknya yang lulusan pondok pesantren itu, kini cuma jadi setengah pengangguran yang tergantung makan dan minumnya pada Nazirah...(hlm. 102)

Nasran, ya Nasran, adiknya itu telah kabur entah kemana, dengan membawa seluruh perhiasan Nazirah dan sebagian besar pakaian Nazirah dan pakaiannya sendiri. (hlm. 159)

Masnub yang hanya seorang guru honorer di Madrasah tidak mempunyai uang untuk mengobati sakitnya sehingga harus berhutang kepada Iqbal dan ketika meninggal ia mewariskan hutang yang cukup besar kepada Nazirah. Demikian pula Istiqomah, untuk mencukupi kehidupan sehari-harinya, ia hanya 
bisa mengandalkan bantuan dari Iqbal. Secara ekonomi, Nazirah, Nasran, Masnub, Rafiqah, Istiqomah, Haji Mudrik, Haji Majruri, dan Tasrif yang berlatar pendidikan pesantren tradisional ini sangat bergantung kepada Iqbal yang berpendidikan kejuruan dan sukses sebagai pengusaha tambak udang.

Niat Tasrif untuk kembali pulang ke Gresik sudah tidak dapat ditahan lagi, sebab hampir lima bulan di rumah mertuanya, dia belum punya pekerjaan tetap. Sedang janji Rafiqah dan Nazirah untuk mengajar di sebuah Madrasah tempat almarhum Mansub, tidak pernah bisa terlaksana, dengan alasan belum ada tambahan dana yang cukup untuk memberi honor pada Tasrif sebesar lima puluh ribu rupiah perbulan.

"Batalkan niatmu hendak pulang ke Gresik", cegah Iqbal tegas.

"Asal engkau mau membantu kami, maka urusanmu itu dapat kami atasi", lanjutnya (hlm. 144145)

Nazirah, Nasran, Masnub, Rafiqah, Tasrif, Haji Mudrik, dan Haji Majruri yang berlatar pendidikan pesantren itu tidak hanya tragis karena kesulitan mendapatkan pekerjaan, tetapi pengetahuan agama dan kemampuan bahasa Arabnya pun ternyata masih kalah dengan Iqbal (yang tidak secara khusus belajar di pesantren) serta menjadi "terkungkung dalam tempurung" (hlm. 133), tidak dapat mengerti atau memahami dan menghargai kehidupan di luar komunitasnya.

Sebab Nazirah tak pernah menyadari, jika Iqbal, mantan suaminya itu, berpendididkan jauh lebih tinggi dibandingkan dengan dirinya yang keluaran pondok pesantren. Bahasa Arabnya jauh lebih kental ditimbang Nazirah dan kitab-kitabnya jauh lebih tebal dan berderet diukur dengan kitabnya yang tipis-tipis dan berwarna kuning. (hlm. 94)

Oleh karena itu, Azizah merasa sangat bersyukur telah mengikuti saran pamannya untuk menempuh pendidikan di luar pesantren.

....seandainya dahulu dia tidak mengikuti saran pamannya untuk meneruskan sekolah di Sekolah Perikanan Menengah Atas, mungkin dia akan bernasib sama dengan mereka (hlm. 134)

Kenyataan yang berlawanan diperlihatkan oleh Iqbal dan Azizah. Iqbal keluar dari tradisi pendidikan pesantren dengan memilih sekolah kejuruan. Pendidikan agama dan bahasa Arab ia pelajari sendiri. Oleh karena bekal pendidikan praktis yang diperolehnya, Iqbal dapat merintis usaha tambak udang hingga sukses. Dengan keuntungan yang diperolehnya setiap tahun, ia dapat membantu saudara-saudaranya secara ekonomi, baik dalam bentuk pemberian uang tunai maupun pekerjaan. Ketidakpercayaan Iqbal pada pendidikan pesantren yang hanya mengajarkan membaca Alquian membuat Iqbal menyekolahkan kemenakannya pada Sekolah Perikanan dengan harapan dapat meneruskan usaha tambak udangnya.

Keunggulan pendidikan kejuruan dari pendidikan pesantren dalam KSG tidak hanya diperlihatkan dalam bentuk kesuksesan orangorang berlatar pendidikan kejuruan dalam bidang ekonomi, tetapi juga dalam hal pemahaman agama dan penghargaannya terhadap eksistensi kelompok lain, khususnya seni tradisi Gandrung. Iqbal diperlihatkan sebagai orang yang fasih berbahasa Arab, memahami agama dengan lebih baik dibandingkan saudara-saudaranya yang lulusan pondok. Bekal pendidikan luar pesantren itu pula yang membuat Iqbal dan Azizah berpandangan lebih terbuka, tidak seperti saudara-saudaranya yang memandang negatif seni tradisi, Iqbal dan Azizah melihatnya secara 
"objektif" dan menghargainya sebagai bagian dari pluralitas budaya.

Azizah dikonstruks dan menjadi simbol penerus Iqbal yang dengan gigih mempertahankan nilai-nilai budaya Using yang akomodatif dan terbuka terhadap masuknya budaya lain, menghargai pluralisme, dan sinkretis. Azizah menjadi simbol perlawanan yang akan terus hidup dari kelompok yang tetap ingin menghargai pluralitas budaya Banyuwangi terhadap upaya "penyeragaman" dan penghomogenan yang dilancarkan oleh kaum santri ekseklusif.

\section{E. PENUTUP}

Penerbitan kembali KSG dalam bentuk buku pada tahun 2003 oleh Yayasan yang bergerak dibidang perempuan dan pengembangan budaya, Desantara, merupakan satu tanda bahwa KSG memiliki relevansi dengan bidang tersebut hingga kini. Meskipun secara referensial KSG menunjuk pada masyarakat Banyuwangi dan merupakan simbol perlawanan terhadap kaum santrinya, khususnya santri ekseklusif Muhammadiyah yang memandang negatif seni tradisi, esensi pergulatan konstruksi kelompok santri dan perempuan seni dalam teks KSG masih dan akan tetap aktual. Pandang memandang dan konflik antara kaum santri dengan perempuan seni masih berlangsung hingga kini dan dapat dilacak, baik melalui media cetak maupun elektronik, seperti dalam heboh goyang Inul.

\section{DAFTAR PUSTAKA}

Ahimsa-Putra, Heddy Shri. 2001. Strukturalisme Levi-Strauss: Mitos dan Karya Sastra. Yogyakarta: Galang Press

2002. "Tanda, Simbol, Budaya, dan Ilmu Budaya". Makalah disampaikan dalam Ceramah Kebudayaan di Fakultas Ilmu Budaya, Universitas Gadjah Mada, Yogyakarta pada tanggal 13 Juni

Anoegrajekti, Novi. 2003. "Gandrung demi Hidup Menyisir Malam" dalam Srinthil : Media Perempuan
Multikultur, April 2003. Jakarta: Desantara

. 2003. "Gandrung yang Gandrung : Pandang Memandang Perempuan Seni" dalam Kerudung Santet Gandrung. Jakarta: Desantara

Armaya. 2002. "Upaya Pelestarian Kesenian Banyuwangi di Era Globlalisasi" dalam Majalah Budaya: Jejak. Nomor 02-2002. Banyuwangi: Pusat Studi Budaya Banyuwangi

Darusuprapta. 1984. "Babad Blambangan". Disertasi. Program Pascasarjana Universitas Gadjah Mada Yogyakarta

Fajar, Malik.1994. "Muhammadiyah dan Nahdathul Ulama: Reorientasi Wawasan Pendidikan" dalam Muhammadiyah dan NU Reorientasi Wawasan Keislaman. Yunahar Iljas (Ed.). Cet. Ke-2. Yogyakarta : LPPI UMY, LKPSM NU, dan PP AlMukhsin Yogyakarta

Geerzt, Clifford. 1981. Abangan, Santri, Priyayi dalam Masyarakat Jawa. Jakarta: Pustaka Jaya . 2000. Tafsir Budaya. Terjemahan F. Budi Hardiman. Yogyakarta: Kanisius

Kuntowijoyo. 1987. Budaya dan Masyarakat. Yogyakarta : Tiara Wacana

Masinambow, E.K.M. 2004. "Teori Kebudayaan dan Ilmu Pengetahuan Budaya" dalam Semiotika Budaya (Ed.) Tommy Christomy dan Untung Yuwono. Depok: Pusat Penelitian kemasyarakatan dan Budaya Direktorat Riset dan Pengabdian Masyarakat Universitas Indonesia

Pasha, Musthafa kemal dan Adaby Darban. 2002. Muhammadiyah Sebagai Gerakan Islam: Perspektif Historis dan Ideologis. Yogyakarta: LPPI Universitas Muhammadiyah

Saputra, Heru Setyapuji. 2003. "Mantra Sabuk Mangir dan Jaran Goyang dalam Budaya Using di Banyuwangi”. Tesis. Program Pasca Sarjana Universitas Gadjah Mada Yogyakarta 
Singodimayan, Hasnan. 2003. Kerudung Santet Gandrung. Jakarta: Desantara . 2002. "Sastra Using dalam Puisi Gending". Makalah disampaikan dalam Diskusi Sastra Jawa Timur di Graha Pena Surabaya bulan Oktober . 1999. "Whong Using Komunitas Asli B a n y u a n g i " d a 1 a m apakabar@radix.net

Sri Soeprihati, Woro. 2001. "Drama Tari Rengganis di Desa Cluring Banyuwangi Jawa Timur". Tesis. Program Pasca Sarjana Universitas Gadjah Mada Yogyakarta
Sup. 2002. "Gandrung Banyuwangi". Http://www.indosiar.com

Suyono, Bambang. 1998. "Gandrung Banyuwangi Sebagai Identitas Budaya Masyarakat Osing di Jawa Timur". Tesis. Program Pasca Sarjana Universitas Gadjah Mada Yogyakarta

Willis, Endro. 2002. "Istilah 'Using' Adalah Racun yang Melumpuhkan Jiwa" dalam Majalah Budaya Jejak nomor 02 